This item was submitted to Loughborough's Research Repository by the author.

Items in Figshare are protected by copyright, with all rights reserved, unless otherwise indicated.

\title{
Removal of antiretroviral drugs stavudine and zidovudine in water under UV254 and UV254/H2O2 processes: Quantum yields, kinetics and ecotoxicology assessment
}

\section{PLEASE CITE THE PUBLISHED VERSION}

https://doi.org/10.1016/j.jhazmat.2018.01.052

\section{PUBLISHER}

(C) Crown Copyright Published by Elsevier

\section{VERSION}

AM (Accepted Manuscript)

\section{PUBLISHER STATEMENT}

This work is made available according to the conditions of the Creative Commons Attribution-NonCommercialNoDerivatives 4.0 International (CC BY-NC-ND 4.0) licence. Full details of this licence are available at: https://creativecommons.org/licenses/by-nc-nd/4.0/

\section{LICENCE}

CC BY-NC-ND 4.0

\section{REPOSITORY RECORD}

Russo, Danilo, A. Siciliano, M. Guida, Roberto Andreozzi, Nuno M. Reis, Gianluca Li Puma, and Raffaele Marotta. 2018. "Removal of Antiretroviral Drugs Stavudine and Zidovudine in Water Under UV254 and UV254/H2O2 Processes: Quantum Yields, Kinetics and Ecotoxicology Assessment". figshare. https://hdl.handle.net/2134/32719. 


\section{Loughborough University Institutional Repository}

\section{Removal of antiretroviral drugs stavudine and zidovudine in water under UV254 and UV254/H2O2 processes: Quantum yields, kinetics and ecotoxicology assessment}

This item was submitted to Loughborough University's Institutional Repository by the/an author.

Citation: RUSSO, D. ...et al., 2018. Removal of antiretroviral drugs stavudine and zidovudine in water under UV254 and UV254/H2O2 processes: Quantum yields, kinetics and ecotoxicology assessment. Journal of Hazardous Materials, 349 , pp. $195-204$.

Additional Information:

- This paper was accepted for publication in the journal Journal of Hazardous Materials and the definitive published version is available at https://doi.org/10.1016/j.jhazmat.2018.01.052

Metadata Record: https://dspace.lboro.ac.uk/2134/32719

Version: Accepted for publication

Publisher: (c) Crown Copyright Published by Elsevier

Rights: This work is made available according to the conditions of the Creative Commons Attribution-NonCommercial-NoDerivatives 4.0 International (CC BY-NC-ND 4.0) licence. Full details of this licence are available at: https://creativecommons.org/licenses/by-nc-nd/4.0/

Please cite the published version. 
Hazardous Materials

Elsevier Editorial System(tm) for Journal of

Manuscript Draft

Manuscript Number: HAZMAT-D-17-03351

Title: Removal of antiretroviral drugs stavudine and zidovudine in water under UV254 and UV254/H2O2 processes: quantum yields, kinetics and ecotoxicology assessment

Article Type: Research Paper

Keywords: photodegradation; microreactor; mutagenicity and genotoxicity; water reuse; antiretroviral

Corresponding Author: Professor Raffaele Marotta, Ph.D

Corresponding Author's Institution: University

First Author: Danilo Russo

Order of Authors: Danilo Russo; Antonietta Siciliano; Marco Guida; Roberto Andreozzi; Nuno M Reis; Gianluca Li Puma; Raffaele Marotta, Ph.D

Abstract: The concentration of antiretroviral drugs in wastewater treatment plants (WWTP) effluents and surface waters of developed and developing countries, especially in the African region more affected by HIV, has increased significantly in recent years due to their widespread use. The presence of antiretroviral in natural water bodies limits the possibility of reuse of such waters, after traditional disinfection process (i.e. UV, chlorine) for civil and irrigation purposes. The removal of stavudine and zidovudine under UV254 or UV254/H2O2 irradiation was investigated in distilled water. The quantum yield of direct photolysis and the kinetic constant of reaction of hydroxyl radical with the antiretrovirals at different pH have been evaluated. A battery of ecotoxicological tests (i.e. inhibition growth, bioluminescence, mutagenic and genotoxic activity) using different living organisms belonging to bacteria (Aliivibrio fischeri, Salmonella typhimurium), crustacean (Dapnia magna) and algae (Raphidocelis subcapitata) revealed a marked influence of the UV dose absorbed by the solution during the photolytic processes on the ecotoxic activity. 


\section{Novelty}

We present for the first time a kinetic and ecotoxicological investigation on the removal with $\mathrm{UV}_{254}$-assisted processes of two antiretrovirals (stavudine and zidovudine) from milli-Q water through a microphotoreactor, which allows very fast experimentation with minimal sample volumes. Zidovudine and stavudine are new emerging poor biodegradable microcontaminants detected in STP effluents and surface waters, especially in African countries, due to the highest incidence of HIV-positive people. Recently, the level of zidovudine in Kenian surface waters increased up to three order of magnitude. Moreover, these substances have been demonstrated to exert a carcinogenic activity. For this purpose, the ecotoxicity of solutions was evaluated to assess genotoxicity and mutagenicity. 


\section{Removal of antiretroviral drugs stavudine and zidovudine in water under $\mathrm{UV}_{254}$ and $\mathrm{UV}_{254} / \mathrm{H}_{2} \mathrm{O}_{2}$ processes: quantum yields, kinetics and ecotoxicology assessment}

Danilo Russo ${ }^{\mathrm{a}}$, Antonietta Siciliano ${ }^{\mathrm{b}}$, Marco Guida ${ }^{\mathrm{b}}$, Roberto Andreozzi ${ }^{\mathrm{a}}$, Nuno M. Reis ${ }^{\mathrm{d}}$, Gianluca Li Puma ${ }^{\mathrm{e}, \star}$ and Raffaele Marotta ${ }^{\mathrm{a}, \uparrow}$

a Dipartimento di Ingegneria Chimica, dei Materiali e della Produzione Industriale, Università di Napoli Federico II, p.le V. Tecchio 80, Napoli, Italy.

${ }^{\mathrm{b}}$ Dipartimento di Biologia, Università di Napoli Federico II, Complesso Universitario Monte Sant'Angelo, via Cinthia 4, Napoli, Italy.

c Dipartimento di Scienze Chimiche, Università di Napoli Federico II, Complesso Universitario Monte Sant'Angelo, via Cinthia 4, Napoli, Italy.

${ }^{\mathrm{d}}$ Department of Chemical Engineering, University of Bath, Claverton Down, Bath BA2 7AY, UK.

e Environmental Nanocatalysis \& Photoreaction Engineering Department of Chemical Engineering, Loughborough University, Loughborough LE11 3TU, UK.

† Corresponding author: Tel.: +39(0)817682968, fax: +39(0)815936936. E-mail address: rmarotta@unina.it (R. Marotta).

$\$$ Corresponding author: Tel.: +44(0)1509222510, fax: +44(0)1509223923. E-mail address: G.Lipuma@lboro.ac.uk (G. Li Puma). 


\section{ABSTRACT}

The concentration of antiretroviral drugs in wastewater treatment plants (WWTP) effluents and surface waters of developed and developing countries, especially in the African region more affected by HIV, has increased significantly in recent years due to their widespread use. The presence of antiretroviral in natural water bodies limits the possibility of reuse of such waters, after traditional disinfection process (i.e. UV, chlorine) for civil and irrigation purposes. The removal of stavudine and zidovudine under $\mathrm{UV}_{254}$ or $\mathrm{UV}_{254} / \mathrm{H}_{2} \mathrm{O}_{2}$ irradiation was investigated in distilled water. The quantum yield of direct photolysis and the kinetic constant of reaction of hydroxyl radical with the antiretrovirals at different $\mathrm{pH}$ have been evaluated. A battery of ecotoxicological tests (i.e. inhibition growth, bioluminescence, mutagenic and genotoxic activity) using different living organisms belonging to bacteria (Aliivibrio fischeri, Salmonella typhimurium), crustacean (Dapnia magna) and algae (Raphidocelis subcapitata) revealed a marked influence of the UV dose absorbed by the solution during the photolytic processes on the ecotoxic activity.

Keywords: photodegradation, microreactor, mutagenicity, genotoxicity, water reuse, zidovudine, stavudine, antiretroviral.

\section{Introduction}

In the last decades, as a result of the widespread availability of pharmaceutical drugs, occurrence, identification, quantification, removal and environmental fate of these emerging contaminants have received significant critical attention [1-3]. Among this new and increasingly growing class of water microcontaminants, the presence of antiretroviral drugs (ARVs) in wastewater and surface water has been the focus of recent research [4-9]. Since their introduction into the market in the early 90s, ARVs have rapidly spread across the world 
because of their effectiveness in the treatment of the HIV virus [10]. In fact, ARVs inhibit the reverse transcriptase of the HIV virus, repressing viral replication [11]. The most commonly used ARVs include zidovudine (ZDV), stavudine (STV), lamivudine, abacavir and nevirapine which are usually administered as a combination therapy to increase their effectiveness in preventing HIV reproduction [12]. ZDV was the first marketed antiretroviral [12] and is still one of the most widely used. STV is also one of the most common ARVs, despite presenting several side effects, because of its relatively low price [13]. Collectively, ARVs increase the life expectancy of HIV-positive patients, however, significant concerns have been raised about their simultaneous release to the environment $[4,5,9]$. New concerns are also related to their consumption in the illicit drugs nyaope [14] and whoonga [15]. As a result, STV and ZDV have been often detected in effluents of wastewater treatment plants (WWTPs) and in natural surface water, in Europe and in Africa, at levels of tens of ng. $\mathrm{L}^{-1}$ up to hundreds of $n g \cdot \mathrm{L}^{-1}$ (Table 1$)$.

In Europe, the main ARVs contamination route of natural waters is through human body excretion and subsequent release in the sewage system [9]. The further presence of ARVs in the effluents of WWTPs and surface water demonstrates the inefficiency of current WWTPs treatment methods. The highest concentrations have been detected in Kenya and South Africa. The levels of ZDV and STV in these African countries, have been shown to be higher in surface water compared to WWTPs effluents, which contrast with the general trend in Europe. The level of ZDV in Kenian surface waters increased up to three order of magnitude during the period 2012 to 2016 [16,18]. Recently, ZDV has also been detected in groundwater [16] which can be probably ascribed to the illicit use and direct spillage in water.

It has been reported [7] that ZDV is not completely removed in conventional treatment plants, a conclusion also shown for an aerobic and anaerobic WWTP in Germany [9], 
although, these authors reported $68 \%$ of ZDV removal in different German WWTP with an activated sludge system. Further biological treatment studies performed in synthetic wastewater demonstrated that $\mathrm{ZDV}$ is non biodegradable, toxic, and inhibitory to activated sludge bacteria [22]. Higher removals have been reported for STV through activated sludge (> 78\%) and biological treatment (> 89\%) [7,9]. Even though the reported LC $_{50}$ (Daphnid acute $48 \mathrm{~h}$ ) are $980 \mathrm{mg} \cdot \mathrm{L}^{-1}$ and higher than $100 \mathrm{mg} \cdot \mathrm{L}^{-1}$ for STV and ZDV respectively [2325], synergistic and mutagenic effects on the aquatic fauna and humans cannot be ruled out. For example, ZDV has been demonstrated to have carcinogenic potential [26]. Advanced oxidation processes (AOPs) have increasingly been proposed as effective tertiary treatments for the removal of biorecalcitrant emerging contaminants [27,28]. Among these, the $\mathrm{UV}_{254} / \mathrm{H}_{2} \mathrm{O}_{2}$ is considered one of the most convenient process since it can be simply applied in existing municipal water treatment plants adopting $\mathrm{UV}_{254}$ lamps for water disinfection, such as treatment plants for water reuse and tertiary units in conventional STP [29]. Notably, reclaimed water reuse for irrigation is especially suitable in water stressed areas [30], which often also present the highest incidence of HIV-positive people, such as Central and South Africa. In spite of the apparent effectiveness of AOPs in micropollutants removal, the potential for the formation of highly toxic by-products [31,32] calls for longer treatment times and for the further evaluation of the ecotoxicity of the treated water. In this study the kinetics of ZDV and STV direct photolysis under $\mathrm{UV}_{254}$ radiation and in the presence of hydrogen $\left(\mathrm{UV}_{254} / \mathrm{H}_{2} \mathrm{O}_{2}\right)$ was investigated in order to estimate important photo-kinetic parameters, such as the quantum yields and the second-order kinetic constant of reaction between $\mathrm{OH}$ radicals and the compounds, which are necessary for design and retrofitting of water treatment plants. The reaction kinetics were investigated by means of a recent developed methodology which used microcapillary photoreactor systems [33], previously adopted for the investigation of the photolytic kinetics of other micropollutants [34-36]. The 
use of this new microphotoreactor technology has been shown to be particularly suitable for the study on highly priced, hazardous, or poorly available water contaminants since it allows to run the entire experimental campaign using minimal amount of compounds, in this case less than $50 \mathrm{mg}$ of ZDV and STV.

The implementation of water reclamation systems and of the environmental risks posed by the effluents, requires comprehensive ecotoxicological assessment on a set of biological tests on species at different trophic levels [37]. For this purpose, the three most frequently ecotoxicity bioassays in aquatic systems are the assessment on Aliivibrio fischeri and Daphnia magna tests for acute toxicity and the Raphidocelis subcapitata test for chronic toxicity. Although these target organisms have often been used to assess the impact of contaminated water, the main focus of water quality testing should also concern organismsdependent chemical-physical and biological properties of the target molecules. In particular, several studies have demonstrated that ARVs differ in genotoxic potency, chromosomal damage and aberration types induced in vitro and in perinatally exposed mice and infants [3840].

In consequence, in the present study we investigated the ecotoxicity of untreated and treated solutions of ZDV and STV using a battery of ecologically relevant testing species to assess the acute and chronic toxicities and genotoxicity and mutagenicity.

\section{Experimental}

\subsection{Materials}

Zidovudine (> 99\%), stavudine ( $>98 \%), \mathrm{NaOH}(\geq 98 \%), \mathrm{H}_{2} \mathrm{SO}_{4}(98 \%)$, hydrogen peroxide (30\% in $\left.\mathrm{H}_{2} \mathrm{O}\right)$, acetonitrile $(\geq 99.9 \%)$, methanol $(\geq 99.9 \%)$, phosphoric acid $\left(85 \%\right.$ in $\left.\mathrm{H}_{2} \mathrm{O}\right)$, catalase from Micrococcus lysodeikticus, $\mathrm{CaCl}_{2} \cdot 2 \mathrm{H}_{2} \mathrm{O}(\geq 99.5 \%), \mathrm{MgSO}_{4} \cdot 7 \mathrm{H}_{2} \mathrm{O}(\geq 98 \%)$, $\mathrm{NaHCO}_{3}(\geq 99.5 \%), \mathrm{KCl}(\geq 99 \%), \mathrm{NH}_{4} \mathrm{Cl}(\geq 99.9 \%), \mathrm{MgCl}_{2} \cdot 6 \mathrm{H}_{2} \mathrm{O}(\geq 98 \%), \mathrm{KH}_{2} \mathrm{PO}_{4}(\geq$ 
$99 \%), \mathrm{FeCl}_{3} \cdot 6 \mathrm{H}_{2} \mathrm{O}(\geq 98 \%), \mathrm{Na}_{2} \mathrm{EDTA} \cdot 2 \mathrm{H}_{2} \mathrm{O}(\geq 99.9 \%), \mathrm{H}_{3} \mathrm{BO}_{3}(\geq 99 \%), \mathrm{MnCl}_{2} \cdot 4 \mathrm{H}_{2} \mathrm{O}(\geq$ 98\%), $\mathrm{ZnCl}_{2}(\geq 99 \%), \mathrm{CoCl}_{2} \cdot 6 \mathrm{H}_{2} \mathrm{O}(\geq 98 \%), \mathrm{Na}_{2} \mathrm{MoO}_{4} \cdot 2 \mathrm{H}_{2} \mathrm{O}(\geq 98 \%)$ and $\mathrm{CuCl}_{2} \cdot 2 \mathrm{H}_{2} \mathrm{O}(\geq$ 98\%) were all purchased from Sigma-Aldrich and used as received.

Reconstitution solution, osmotic adjusting solution (OAS) and diluent $(\mathrm{NaCl} 2 \%)$ were the reagents used for the Aliivibrio fischeri toxicity test (Strategic diagnostics Inc. SDI). All the reacting solutions were prepared adding the contaminants and hydrogen peroxide to milliQ water. When necessary, $\mathrm{pH}$ was adjusted by using dilute aqueous solutions of $\mathrm{NaOH}$ and $\mathrm{H}_{2} \mathrm{SO}_{4}$.

\subsection{Photolytic treatments}

A microcapillary film (MCF) array photoreactor was used to perform the $\mathrm{UV}_{254}$ photolysis and $\mathrm{UV}_{254} / \mathrm{H}_{2} \mathrm{O}_{2}$ experiments. A detailed description and a scheme of the reactor can be found elsewhere [33,34]. Briefly, the polymeric film microreactor consists of ten tubular microcapillaries (Lamina Dielectrics Ltd, Billingshurst, West Sussex, UK) with a mean hydraulic diameter of $195 \mu \mathrm{m}$ and an average optical path length of $152 \mu \mathrm{m}$. The MFC was fed by means of a syringe pump (HA Harvard Apparatus PHD Ultra) and wrapped around a germicidal lamp (Germicidal G8T5, Ge Lighting) emitting at $254 \mathrm{~nm}$. The nominal lamp power could be varied from 8.0 to $4.5 \mathrm{~W}$ with the use of a switch power supplier. The emitted photon fluxes per unit volume $\left(I_{0} / V\right)$ were estimated by hydrogen peroxide actinometry $[41,42]$ and were $1.92 \cdot 10^{-2}$ ein $\cdot \mathrm{s}^{-1} \cdot \mathrm{L}^{-1}$ and $1.27 \cdot 10^{-2} \mathrm{ein} \cdot \mathrm{s}^{-1} \cdot \mathrm{L}^{-1}$, respectively. The residence time (space time) through the MFC was varied changing the length of the film exposed to the light. Samples were collected at the outlet of the MFC after reaching steady state conditions, and rapidly analyzed by HPLC. Neglegible temperature differences $\left(\sim 25{ }^{\circ} \mathrm{C}\right)$ between the inlet and the outlet samples were found in all the experiments. All the experimental runs were 


\subsection{Analytical methods}

ZDV, STV, and hydrogen peroxide concentrations were measured by HPLC (1100 Agilent) equipped with a Gemini 5u C6-Phenyl (260 x $4.60 \mathrm{~mm})$ (Phenomenex) column. An isocratic method was used for the simultaneous quantification of ZDV and hydrogen peroxide with mobile phase $\left(0.8 \mathrm{~mL} \cdot \mathrm{min}^{-1}\right)$ made of $93 \%$ aqueous phosphoric acid $(10 \mathrm{mM})$ and $7 \%$ acetonitrile. Under these analytical conditions the retention times of hydrogen peroxide and ZDV were 4.1 and 13.7 min, respectively. The mobile phase was changed to $80 \%$ water and 
$20 \%$ methanol for the simultaneous identification of $\mathrm{H}_{2} \mathrm{O}_{2}$ and STV with retention times of 3.7 and $10 \mathrm{~min}$, respectively. The signals were acquired at $266 \mathrm{~nm}$.

The molar absorption coefficients of STV and ZDV were estimated using a Perkin Elmer UV/VIS spectrometer (mod. Lambda 35).

\subsection{Ecotoxicological methods}

\subsubsection{Toxicity test with Daphnia magna}

The test was conducted in accordance with ISO 6341 [43]. Every test was performed in quadruplicate with four control groups. Briefly, neonates aged less than 24 hours were separated into four groups and exposed to different concentrations of untreated and treated solutions of ZDV and STV. All tests were carried out at constant temperature $\left(20 \pm 2{ }^{\circ} \mathrm{C}\right)$ and in darkness and organisms were not fed during the experiments. After $48 \mathrm{~h}$ exposure, daphnids that were not able to swim within 15 seconds under gentle agitation were considered to be immobilized.

\subsubsection{Bacteria toxicity test}

The Microtox ${ }^{\circledR}$ SPT procedure [44] was used to evaluate the acute toxicity of the samples using as endpoint the bioluminescence inhibition of the naturally emitted by A. fischeri (strain NRRL-B-11177) after a contact time of $30 \mathrm{~min}$ with the test sample. The samples were serially diluted to a series of four concentrations, then a volume of $10 \mu \mathrm{L}$ of reconstituted bacterial reagent was added to dilutions series of samples. The emission of bioluminescence was recorded after $30 \mathrm{~min}$ of contact time with the bacteria at $15 \pm 2{ }^{\circ} \mathrm{C}$. 


\subsubsection{Algal growth inhibition test with Raphidocelis subcapitata}

The growth inhibition test was assessed following the ISO 8692:2012 standard procedure [45]. Exponentially growing algae $\left(10^{4} \mathrm{cell} \cdot \mathrm{mL}^{-1}\right)$ were exposed to various concentrations of the test samples in six replicates over a period of $72 \mathrm{~h}$ under defined conditions, as described elsewhere [46]. Growth and inhibition were quantified from measurements of the algal biomass density (cell counts) as a function of time. The specific growth rate of $R$. subcapitata in each replicate culture was calculated from the logarithmic increase in cell density in the intervals from 0 to $72 \mathrm{~h}$ using the following equation: $\mu=\frac{\ln N_{n}-\ln N_{0}}{t_{n}-t_{0}}$, where $\mathrm{N}_{0}$ is the cell concentration at $\mathrm{t}=0, \mathrm{~N}_{\mathrm{n}}$ the final cell concentration after $72 \mathrm{~h}$ of exposure, $\mathrm{t}_{0}$ the time of start measurement, and $t_{n}$ the time of last measurement (hours from start). The results were expressed as the mean ( \pm standard deviation) of the percentage inhibition of the cell growth (\% I) of the sample compared with the negative control $(\mathrm{p} \leq 0.05)$.

\subsubsection{Mutagenicity assay with Salmonella typhimurium}

The Muta-Chromoplate kit was used to evaluate the mutagenicity [47]. The fluctuation tests were performed using S. typhimurium strains TA100 and observing the potential his- reverse mutation after exposure to mutagens [48].

Bacteria cultures, grown overnight and reaching the exponential growth phase, were exposed for 5 days at $37^{\circ} \mathrm{C}$ to different samples concentrations, in a liquid medium into 96-well microtiter plates. After this period, the positives samples wells that turned yellow were counted, while the purple wells were considered as negatives. The reversion of mutants (his +) exhibited the yellow color due to the acidification of the test medium resulting from the growth of reverse mutants. The number of his + revertant colonies in each sample was determined as a mean value of the three plates. The results were expressed as a mutagenicity ratio (MR), i.e. the ratio of the number of S. typhimurium revertants grown in the presence of 


\subsubsection{Genotoxicity assay with Salmonella typhimurium}

The umu test [50] was performed according to standard procedure [51], which was developed for the detection of genotoxic materials that cause DNA cell damage. In this assay, a modified strain of $S$. typhimurium TA1535/pSK 1002 bacteria was used, whereby a $\beta$ galactosidase gene was linked to SOS-DNA response. Bacterial cultures were grown overnight at $37^{\circ} \mathrm{C}$ and then diluted in TGA medium (Tryptone-Glucose-Ampicillin medium) until the cells entered the logarithmic growth phase. The cells were then exposed to the test samples for 2 hours. The induction of genotoxicity (expressed as $\beta$-galactosidase activity) was determined colorimetrically at $420 \mathrm{~nm}$ after adding o-nitrophenyl galactopyranoside to the samples. Growth was measured as the absorbance at a wavelength of $600 \mathrm{~nm}$. The result was calculated as an induction ratio, $I R=(1 / \mathrm{G}) \cdot \mathrm{US}$, where $\mathrm{G}$ was the growth and US the relative enzyme activity. The sample was considered genotoxic when IR was greater than 1.5. The significance of the differences between the mean values of different tests and controls was assessed by Student's test and analysis of variance (ANOVA) with a 0.05 significance level. Moreover, post-hoc analysis were carried out by Tukey's test [52].

\section{Results and Discussion}

\subsection{Absorbance spectra}

The absorbance spectra of ZDV (Fig. 1a) and STV (Fig. 1b) at pH 4.0, 6.5 and 8.0 showed invariance in the $\mathrm{pH}$ range from 4.0 to 8.0 for ZDV and from 6.5 - to 8.0 for STV. Since $\mathrm{pH}$ did not affect ZDV and STV degradation kinetics in the $\mathrm{pH}$ ranges 4.0-8.0 and 6.0-8.0, 
respectively, the reaction kinetics were investigated in the slightly acidic to alkaline $\mathrm{pH}$ range from 6.0 to 8.0 , which also is more environmentally relevant. The estimated molar absorption coefficients at $254 \mathrm{~nm}$ are summarized in Table 2.

\subsection{ZDV and STV direct photolysis and quantum yield estimation}

The quantum yield $\left(\phi_{i}^{254}\right)$ of direct photolysis at $254 \mathrm{~nm}$ was determined with different sets of experimental runs carried out in the MCF varying the ARV initial concentration, the $\mathrm{pH}$ and the lamp power (Table 3). The degradation of the generic ARV by direct photolysis follows the mass balance (eq. 1):

$\frac{d C_{i}}{d t}=-\frac{I_{0}}{V} \cdot \phi_{i}^{254} \cdot\left(1-\exp \left(-2.3 \cdot l \cdot \varepsilon_{i}^{254} \cdot C_{i}\right)\right)$

where $C_{i}$ is the concentration of $\mathrm{ARV}, I_{0} / V$ is the photon flux per unit volume, $l$ is the average optical length of the reactor (see Photolytic treatments section), and $\varepsilon_{i}^{254}$ the molar absorption coefficient of the ARV species (Table 2). A Matlab optimization routine based on the Runge-Kutta method was adopted to determine the value of $\phi_{i}^{254}$ which minimized the objective function (optimisation mode):

$\sum_{j}^{m} \sum_{i}^{n}\left(y_{j, i}-c_{j, i}\right)^{2}$

where $c$ and $y$ are the experimental and calculated concentrations at different reaction times $(n)$ and experimental runs $(m)$. Table 3 shows the estimated quantum yields and the 97\% interval of confidence of ZDV and STV. The results corroborate with the previous photolytic decomposition investigation [53], that reported higher sensitivity of ZDV to UVA light compared to STV, with a fluorescent irradiation source in the wavelength spectra from 320 $\mathrm{nm}$ to $400 \mathrm{~nm}$.

All the adopted experimental runs used for the kinetic modeling along with the experimental conditions and the average standard deviation are reported in Table 4 whereas Fig. 2 (a-d) 


\subsection{Kinetic modeling of $U V_{25} / \mathrm{H}_{2} \mathrm{O}_{2}$ process}

The second order rate constant $k_{O H, i}$ of the reaction between ZDV and STV with hydroxyl radicals was estimated from a set of experimental runs carried out in the MCF at varying $\mathrm{pH}$, lamp power and $C_{\mathrm{H}_{2} \mathrm{O}_{2}} / C_{i}$ molar ratio (Table 5). They were modeled according to the following simplified reaction scheme:

$\mathrm{H}_{2} \mathrm{O}_{2} \stackrel{\phi_{H_{2} \mathrm{O}_{2}}^{254}}{\longrightarrow} 2 \mathrm{HO}^{\circ}$

$A R V \stackrel{\phi_{i}^{254}}{\longrightarrow} S$

$A R V+H O \cdot \stackrel{k_{O H, i}}{\longrightarrow} P$

$P+H O \stackrel{\mathrm{k}_{\mathrm{OH}, i}}{\longrightarrow} P^{\prime}$

$S+H O \stackrel{\mathrm{KOH}^{\prime},}{\longrightarrow} S^{\prime}$

$\mathrm{H}_{2} \mathrm{O}_{2}+\mathrm{HO}^{\bullet} \stackrel{k_{H}}{\rightarrow} \mathrm{HO}_{2}^{\cdot}+\mathrm{H}_{2} \mathrm{O}$

$2 \mathrm{HO}_{2} \stackrel{k_{t}}{\rightarrow} \mathrm{O}_{2}+\mathrm{H}_{2} \mathrm{O}_{2}$

$$
\begin{aligned}
\varepsilon_{H_{2} O_{2}}^{254} & =18.6 \mathrm{M}^{-1} \cdot \mathrm{cm}^{-1}[54] \\
\emptyset_{\mathrm{H}_{2} \mathrm{O}_{2}}^{254} & =0.55 \mathrm{~mol} \cdot \mathrm{ein}^{-1}[54]
\end{aligned}
$$

(estimated in this work)

(estimated in this work)

(estimated in this work)

(estimated in this work)

$k_{H}=2.7 \cdot 10^{7} M^{-1} \cdot s^{-1}[55]$

$k_{t}=8.3 \cdot 10^{5} \mathrm{M}^{-1} \cdot \mathrm{s}^{-1}[56]$

Hydroxyl radicals formed by direct photolysis of hydrogen peroxide under $\mathrm{UV}_{254}$ radiation $\left(\mathrm{r}_{1}\right)$ attack the $\mathrm{ARV}\left(\mathrm{r}_{3}\right)$, the $\mathrm{P}$ and $\mathrm{S}$ pseudo by-products formed $\left(\mathrm{r}_{4}-\mathrm{r}_{5}\right)$, and the oxidant hydrogen peroxide which generates hydroperoxyl radicals $\left(\mathrm{r}_{6}\right)$. The latter recombine according to the termination reaction $\left(\mathrm{r}_{7}\right)$ to form $\mathrm{H}_{2} \mathrm{O}_{2}$. The simultaneous photolysis of ARV is considered in reaction $\left(\mathrm{r}_{2}\right)$. Assuming that hydroxyl radicals attack both substrate and the first generation of chemical intermediates with the same rate constant $k_{O H, i}$ and that at any 
reaction time the sum of the unconverted substrate $\left(C_{i}\right)$ and its by-products $\left(C_{P, S}\right)$ concentration is equal to the initial antiretroviral concentration $\left(C_{o}\right)$ :

$$
C_{o}=C_{i}+C_{P, S}
$$

the concentrations of hydroxyl and hydroperoxyl radicals, under the steady state approximation equal:

$$
\begin{gathered}
{\left[\mathrm{HO}^{\bullet}\right]_{S S}=\frac{2 F_{\mathrm{H}_{2} \mathrm{O}_{2}}}{k_{\mathrm{OH}, i} \cdot C_{O}+k_{\mathrm{H}} \cdot C_{\mathrm{H}_{2} \mathrm{O}_{2}}}} \\
{\left[\mathrm{HO}_{2}^{\bullet}\right]_{s s}{ }^{2}=\frac{F_{\mathrm{H}_{2} \mathrm{O}_{2}} \cdot k_{\mathrm{H}} \cdot C_{\mathrm{H}_{2} \mathrm{O}_{2}}}{k_{t}\left(k_{\mathrm{OH}, i} \cdot C_{O}+k_{\mathrm{H}} \cdot C_{\mathrm{H}_{2} \mathrm{O}_{2}}\right)}}
\end{gathered}
$$

where

$F_{\mathrm{H}_{2} \mathrm{O}_{2}}=\frac{I_{0}}{V} \cdot \phi_{\mathrm{H}_{2} \mathrm{O}_{2}}^{254} \cdot\left(1-\exp \left(-2.3 \cdot l \cdot\left(\varepsilon_{\mathrm{H}_{2} \mathrm{O}_{2}}^{254} \cdot C_{\mathrm{H}_{2} \mathrm{O}_{2}}+\varepsilon_{i}^{254} \cdot C_{i}\right)\right)\right) \cdot \frac{\varepsilon_{\mathrm{H}_{2} \mathrm{O}_{2}}^{254} \cdot C_{\mathrm{H}_{2} \mathrm{O}_{2}}}{\varepsilon_{\mathrm{H}_{2} \mathrm{O}_{2}}^{254} \cdot C_{\mathrm{H}_{2} \mathrm{O}_{2}}+\varepsilon_{i}^{254} \cdot C_{i}}$

and the concentration of $\mathrm{H}_{2} \mathrm{O}_{2}$ and $\mathrm{ARV}$ s versus time can be determined by solving the following material balance:

$$
\begin{aligned}
& \frac{d C_{\mathrm{H}_{2} \mathrm{O}_{2}}}{d t}=-F_{\mathrm{H}_{2} \mathrm{O}_{2}}-\frac{k_{\mathrm{H}} \cdot C_{\mathrm{H}_{2} \mathrm{O}_{2}} \cdot F_{\mathrm{H}_{2} \mathrm{O}_{2}}}{k_{\mathrm{OH}, i} \cdot C_{O}+k_{\mathrm{H}} \cdot C_{\mathrm{H}_{2} \mathrm{O}_{2}}} \\
& \frac{d C_{i}}{d t}=-F_{i}-\frac{2 k_{O H, i} \cdot C_{i} \cdot F_{\mathrm{H}_{2} \mathrm{O}_{2}}}{k_{\mathrm{OH}, i} \cdot C_{O}+k_{H} \cdot C_{\mathrm{H}_{2} \mathrm{O}_{2}}}
\end{aligned}
$$

where

$$
F_{i}=\frac{I_{0}}{V} \cdot \phi_{i}^{254} \cdot\left(1-\exp \left(-2.3 \cdot l \cdot\left(\varepsilon_{H_{2} O_{2}}^{254} \cdot C_{H_{2} O_{2}}+\varepsilon_{i}^{254} \cdot C_{i}\right)\right)\right) \cdot \frac{\varepsilon_{A R V}^{254} \cdot C_{H_{2} O_{2}}}{\varepsilon_{H_{2} O_{2}}^{254} \cdot C_{H_{2} O_{2}}+\varepsilon_{i}^{254} \cdot C_{i}}
$$

Similarly to the previous analysis, the equations (6-7) were solved by means of an optimization routine to minimize the objective function

$$
\sum_{h=1}^{2} \sum_{j}^{m} \sum_{i}^{n}\left(y_{j, i}-c_{j, i}\right)^{2}
$$


slightly modified to account for the number of reacting species $(h)$. Selected experimental runs were not included in the optimization procedure to validate the kinetic model without further adjustment of the estimated kinetic parameter $k_{O H, i}$. All the runs adopted, along with their average standard deviation, are summarized in Table 5. Figure 3 shows the comparisons between the experimental and calculated data, both in optimization and simulation modes. The second order rate constant of ARVs investigated with hydroxyl radicals is shown in Table 6. The kinetic constant of reaction of hydroxyl radical with ZDV, determined by the competition kinetics method, in literature varies over a wide range: $(1.3 \pm 0.026) \cdot 10^{10} \mathrm{M}^{-1} \cdot \mathrm{s}^{-1}$ determined using para-chlorobenzoic acid as reference compound [57] and $(5.73 \pm 0.76) \cdot 10^{9}$ $\mathrm{M}^{-1} \cdot \mathrm{s}^{-1}$ determined using acetophenone as reference substance [17]. These values are significant higher than the results obtained in this study. One possible explanation for this discrepancy is that the competition kinetics method is only reliable if the contribution of direct photolysis of the investigated compound is absent or negligible. In the absence of that, the $k_{O H, i}$ value tends to be overestimated $\left(k_{O H, i}^{\prime}\right)$ since is also accounts for the contribution of direct photolysis to the degradation. To further clarify this aspect, the competition kinetic method using benzoic acid (BA) as reference compound [58] was also used to estimate the second order rate constant of hydroxyl radicals with ARVs. According to this method the $k^{\prime}{ }_{O H, i}$ value can be calculated according to (10):

$\ln \frac{C_{i}}{C_{o}}=\frac{k_{O H, i}^{\prime}}{k_{O H, B A}} \ln \frac{C_{B A}}{C_{B A_{O}}}$

where $C_{B A}$ and $C_{B A_{o}}$ are the unconverted and initial concentration of benzoic acid, and $k_{O H, B A}$ the kinetic constant of reaction between benzoic acid and hydroxyl radical $\left(5.9 \cdot 10^{9} \mathrm{M}^{-}\right.$ $\left.{ }^{1} \cdot \mathrm{s}^{-1}[55]\right)$. Duplicate experimental runs were carried out under the following conditions: $C_{Z D V_{o}}=2.46 \cdot 10^{-5} \mathrm{M}, C_{B A_{o}}=2.62 \cdot 10^{-5} \mathrm{M}, C_{H_{2} O_{2}}=1.41 \cdot 10^{-3} \mathrm{M}$, and $C_{S T V_{o}}=2.21 \cdot 10^{-5} \mathrm{M}, C_{B A_{o}}=$ $2.15 \cdot 10^{-5} \mathrm{M}, C_{\mathrm{H}_{2} \mathrm{O}_{2}}=9.8 \cdot 10^{-4} \mathrm{M}$. Plotting $\ln C_{i} / C_{O} v s \ln C_{B A} / C_{B A_{o}}, k_{O H, i}^{\prime}$ was estimated as 
6.39.109 $\mathrm{M}^{-1} \mathrm{~s}^{-1}$ and $5.33 \cdot 10^{9} \mathrm{M}^{-1} \mathrm{~s}^{-1}$ for ZDV and STV, respectively. As expected both values overestimate the results reported in Table 6. Moreover, the difference is higher for $\mathrm{ZDV}$, in agreement with the higher significance of direct photolysis in the degradation of this compound compared to STV. It is also important to notice that the $k_{O H, Z D V}^{\prime}$ value estimated in the present study, adopting the competition kinetics method, was within those reported in the literature $[17,57]$.

\subsection{Ecotoxicological assessment}

The inhibition of $A$. fischeri luminescence and D. magna immobility was not observed on untreated and $\mathrm{UV}_{254}$ or $\mathrm{UV}_{254} / \mathrm{H}_{2} \mathrm{O}_{2}$ treated solutions (data not shown). The growth inhibition of algae $R$. subcapitata exposed to ZDV and STV containing solutions before and during the photolytic processes $\left(\mathrm{UV}_{254}\right.$ or $\left.\mathrm{UV}_{254} / \mathrm{H}_{2} \mathrm{O}_{2}\right)$ is shown in Figures 4a-f. A marked different trend in effects on algae growth according to the dose-response correlation was observed. ZDV inhibited slightly algal growth, while STV had insignificant effect (less than 20\%). The toxicity of the treated solutions in both processes slightly increased increasing the UV dose, also for treatment times corresponding to the complete removal of the antiretroviral drugs. In particular, the inhibited algal growth for the ZDV treated solutions increased by $36 \%$ and $44 \%$ when the conversion of ZDV was $90 \%$ and $100 \%$ respectively in both $\mathrm{UV}_{254}$ and $\mathrm{UV}_{254} / \mathrm{H}_{2} \mathrm{O}_{2}$ treatments (Fig. 4a). The same increasing trend of ecotoxicity was observed with the STV treated solutions, although the increase in ecotoxicity to $R$. subcapitata was less significant in comparison to the ZDV treated solutions. The inhibition was $20 \%$ and $30 \%$ when the STV conversions was $90 \%$ and $100 \%$ respectively (Fig. $4 \mathrm{~b}$ ).

The antiretroviral drugs showed marked algae growth activity when the dilution factor of untreated and treated solutions was increased from 1:10 (Figs. 4c-d) to 1:100 (Figs. 4e-f), which appeared to stimulate algal growth with a statistically significant extent. This 
uncommon "apparently beneficial effect" observed at low doses, known as hormesis, has been previously reported for some bioindicators such as crustaceans $[59,60]$ and plants and algae [61] in the presence of nitrogen-containing organic molecules (trinitrotoluene, triazine herbicides, etc.) such as are STV and ZDV.

Tables 7 and 8 summarize the mutagenicity and genotoxicity results. Both antiretrovirals were not able to determine a significant SOS system induction, while variability among the mutagenic responses was observed in the Salmonella mutagenicity assay (threshold value: 2.0). The mutagenicity results indicated that $(i)$ potential mutagenic degradation intermediates could have been formed at significant levels during the photolysis of ZDV than STV, (ii) the mutagenicity of the samples further increased at increasing $\mathrm{UV}_{254}$ doses and (iii) the $\mathrm{UV}_{254} / \mathrm{H}_{2} \mathrm{O}_{2}$ treatment produced less mutagenic intermediate products than those formed during $\mathrm{UV}_{254}$ photolysis. Residual mutagenic activity was also observed on the ZDV samples treated by $\mathrm{UV}_{254}$ photolysis for conversions higher than 90\%, after a 1:1000 dilution (Table 7). It is useful to point out that the concentration of ZDV in these samples was of the same order of magnitude as the values detected in African surface water (Table 1).

During the $\mathrm{UV}_{254} / \mathrm{H}_{2} \mathrm{O}_{2}$ process it was observed a slight increase of revertants followed by disappearance of revertants at the highest $\mathrm{UV}_{254}$ exposure.

Investigations of the genotoxic endpoints demonstrated that the untreated solutions could not be classified as genotoxic since the induction ratio was below the threshold value of 1.5 (Tables 7-8). On the contrary, a statistically significant increase in umuC induction was recorded for ZDV undiluted solutions for $\mathrm{UV}_{254}$ doses corresponding to $\mathrm{ZDV}$ conversions of $45 \%$ and $90 \%$ for both $\mathrm{UV}_{254}$ and $\mathrm{UV}_{254} / \mathrm{H}_{2} \mathrm{O}_{2}$ processes (Table 7). The genotoxic activity showed a decreasing trend as the dilution factor of the solutions increased.

STV genotoxic data demonstrated (Table 8) that only the treated solutions were able to induce a significant SOS response with IF higher than 2 also observed for the highest dilution 
factor $(1: 1000)$, which corresponds to an initial concentration of STV of $4.3 \mu \mathrm{g} \cdot \mathrm{L}^{-1}$. The results collectively may indicate that some photoproducts generated during the photolytic processes could have genotoxic activity. However, genotoxic activity was not observed in the solutions treated for prolonged treatment times, thus suggesting that the genotoxic transformation products observed in earlier times might have further evolved to nongenotoxic metabolites.

\section{Conclusions}

The removal of stavudine and zidovudine by $\mathrm{UV}_{254}$ radiation without and with hydrogen peroxide was investigated in a microcapillary film photoreactor using minimal quantities of water samples. Higher $\mathrm{UV}_{254}$-photolysis quantum yields were observed for zidovudine, $(2.357 \pm 0.0589) \cdot 10^{-2} \mathrm{~mol} \cdot \mathrm{ein}^{-1}$ in the $\mathrm{pH}$ range from 4.0 to 8.0 , while stavudine quantum yield was 28 -fold lower $(8.34 \pm 0.334) \cdot 10^{-4} \mathrm{~mol}^{-\mathrm{ein}^{-1}}$ in the $\mathrm{pH}$ range from 6.0 to 8.0 . The second-order rate constant of reaction with hydroxyl radicals was $(9.98 \pm 0.68) \cdot 10^{8} \mathrm{M}^{-1} \cdot \mathrm{s}^{-1}$ $(\mathrm{pH}$ range $4.0-8.0)$ for zidovudine and $(2.03 \pm 0.18) \cdot 10^{9} \mathrm{M}^{-1} \cdot \mathrm{s}^{-1}(\mathrm{pH}: 6.0-8.0)$ for stavudine. The well known ecotoxicological tests using A. fischeri and D. magna as bioindicators did not evidenced acute or chronic effects. A hormetic effect was observed for the first time in $R$. subcapitata for ZDV and STV treated solutions at different $\mathrm{UV}_{254}$ doses after a dilution from 1:10 to 1:100.

On the contrary, specific tests using Salmonella $t$. revealed mutagenic and genotoxic activity of the ZDV and STV samples also at high dilution factors depending on the type of the photolytic treatment and substrate conversion.

Generally, $\mathrm{UV}_{254}$ photolysis in the presence of hydrogen peroxide reduces the ecotoxicological risk associated to direct photolysis of the aqueous solutions containing the antiretrovirals, but for this purpose $\mathrm{UV}_{254}$ doses $\left(\geq 2000 \mathrm{~mJ} \cdot \mathrm{cm}^{-2}\right)$, significantly higher than 
the levels suggested for the water UV disinfection processes $\left(50-200 \mathrm{~mJ} \cdot \mathrm{cm}^{-2}\right)$ are necessary. This study pointed out the critical importance of selecting suitable bioindicators depending on chemical and biological properties of the selected xenobiotics detected in STP effluents and in surface waters.

\section{Acknowledgements}

The Authors are grateful to ERASMUS-Mobility Student Program, and to Ing. Giulio Di Costanzo for his precious support during the experimental campaign.

\section{References}

[1] B. Petrie, R. Barden, B. Kasprzyk-Hordern, A review on emerging contaminants in wastewater and the environment: current knowledge, understudies areas and recommendations for future monitoring, Wat. Res. 72 (2015) 3-27.

[2] T. Deblonde, C. Cossu-Leguille, P. Hartemann, Emerging pollutants in wastewater: a review of the literature, Int. J. Hyg. Envir. Heal. 214(6) (2011) 442-448.

[3] N. Bolong, A.F. Ismail, M.R. Salim, T. Matsuura, A review of the effects of emerging contaminants in wastewater and options for their removal, Desalination 239(1-3) (2009) 229246.

[4] S. Jain, P. Kumar, R.K. Vyas, P. Pandit, A.K. Dalai, Occurrence and removal of antiviral drugs in environment: a review. Water Air Soil Poll. 224(2) (2013) 1410-1428.

[5] E. Ngumba, A. Gachanja, T. Tuhkanen, Occurrence of selected antibiotics and antiretroviral drugs in Nairobi River Basin, Kenya, Sci. Total Environ. 539 (2016a) 206-213. [6] E. Ngumba, P. Kosunen, A. Gachanja, T. Tuhkanen, A multiresidue analytical method for trace level determination of antibiotics and antiretroviral drugs in wastewater and surface 
water using SPE-LC-MS/MS and matrix-matched standards. Anal. Methods 8 (2016b) 67206729.

[7] T.P. Wood, C.S.J. Duvenage, E. Rohwer, The occurrence of anti-retroviral compounds used for HIV treatment in South African surface water, Environ. Pollut. 199 (2015) 235-243. [8] X. Peng, C. Wang, K. Zhang, Z. Wang, Q. Huang, Y. Yu, W. Ou, Profile and behaviour of antiviral drugs in aquatic environments of the Pearl River Delta, China, Sci. Total Environ. 466-467 (2014) 755-761.

[9] C. Prasse, M.P. Schlusener, R. Schulz, T.A. Ternes, Antiviral drugs in wastewater and surface water: a new pharmaceutical class of environmental relevance? Environ. Sci. Technol. 44 (2010) 1728-1735.

[10] G. Camponeschi, J. Fast, M. Gauval, K. Guerra, M. Moore, S. Ravinutala, D. Ripin, V. Shepel, An overview of the antiretroviral maket, Curr. Opin. HIV AIDS, 8(6) (2013) 535543.

[11] M.J.M. Hitchcock, 2',3'-Didehydro-2',3'-dideoxythymidine (D4T), an anti-HIV agent, Antivir. Chem. Chemother. 2(3) (1991) 125-132.

[12] G. Kumari, R.K. Singh, Highly active antiretroviral therapy for treatment of HIV/AIDS patients: current status and future prospects and the Indian scenario, HIV AIDS Rev. 11 (2012) 5-14.

[13] J.S.F. Lee, L.S. Teyssier, B.D. Nguimfack, I.J. Collins, M. Lallemant, J. Perriens, J. Moatti, J., An analysis of volumes, prices and pricing trends of the pediatric antiretroviral market in developing countries from 2004 to 2012, BMC Pediatrics 16(41) (2016) 1-8.

[14] A.A. Khine, K.E. Mokwena, M. Huma, L. Fernandes, Identifying the composition of street drug nyaope using two different mass spectrometer methods, Afr. J. Drug Alcohol Stud. 14(1) (2015) 49-56. 
[15] D.J. Grelotti, E.F. Closson, J.A. Smit, Z. Mabude, L.T. Matthews, S.A. Safren, D.R. Bangsberg, M.J. Mimiaga, Whoonga: potential recreational use of HIV antiretroviral medication in South Africa, AIDS Behav. 18(3) (2014) 511-518.

[16] K.O. K'oreje, L. Vergeynst, D. Ombaka, P. De Wispelaere, M. Okoth, H. Van Langenhove, K. Demeestere, Occurrence patterns of pharmaceutical residues in wastewater, surface water and groundwater of Nairobi and Kisumu city, Kenya, Chemosphere 149 (2016) $238-244$.

[17] C. Zhou, J. Chen, Q. Xie, X. Wei, Y. Zhang, Z. Fu, Photolysis of three antiviral drugs acyclovir, zidovudine and lamivudine in surface freshwater and seawater. Chemosphere 138 (2015) 792-797.

[18] K.O. K'oreje, K. Demeestere, P. De Wispelaere, L. Vergeynst, J. Dewulf, H. Van Langenhove, From multi-residue screening to target analysis of pharmaceuticals in water: Development of a new approach based on magnetic sector mass spectrometry and application in the Nairobi River basin, Kenya, Sci. Total Environ. 437 (2012) 153-164.

[19] J. Funke, C. Prasse, T.A. Ternes, Identification of transformation products of antiviral drugs formed during biological wastewater treatment and their occurrence in the urban water cycle. Wat. Res. 98 (2016) 75-83.

[20] Y. Aminot, X. Litrico, M. Chambolle, C. Arnaud, P. Pardon, H. Budzindki, Development and application of a multi-residue method, for the determination of 53 pharmaceuticals in water, sediment, and suspended solids using liquid chromatographytandem mass spectrometry. Anal. Bioanal. Chem. 407 (2015) 8585-8604.

[21] A.L.L. Silva, R. Cristofoletti, S. Storpirtis, V.D. Sousa, H.E. Junginger, V.P. Shah, S. Stavchansky, J.B. Dressman, D.M. Barends, Biowaiver monographs for immediate-release solid oral dosage forms: stavudine, J. Pharm. Sci. 101 (2012) 10-15. 
[22] M. Vankova, Biodegradability analysis of pharmaceuticals used in developing countries; screening with OxiTopC-110, Tampere University of Technology, Finland, (p.73), 2010. Roche, 2007.

Pharmaceuticals

sustainability

database.

http://www.roche.com/sustainability/what_we_do/for_communities_and_environment/enviro

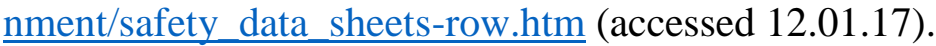

[24] GSK, 2007. Materials safety data sheets from GlaxoSmithKline (GSK). http://www.msds-gsk.com/Default.aspx (accessed 12.01.17).

[25] H. Sanderson, M. Thomsen, Comparative analysis of pharmaceuticals versus industrial chemicals acute aquatic toxicity classification according to the United Nations classification system for chemicals. Assessment of the (Q)SAR predictability of pharmaceuticals acute toxicity and their predominant acute mode-of-action, Toxicol. Lett. 187 (2009) 84-93.

[26] P. Bottoni, S. Caroli, A.B. Caracciolo, Pharmaceuticals as priority water contaminants, Toxicol. Environ. Chem. 92(3) (2010) 549-565.

[27] B.A. Wols, C.H.M. Hofman-Caris, Review of photochemical reaction constants of organic micropolluttants required for UV advanced oxidation processes in water, Wat. Res. 46 (2012) 2815-2827.

[28] M.A. Oturan, J. Aaron, Advanced oxidation processes in water/wastewater treatment: principles and applications. A review, Crit. Rev. Env. Sci. Tech. 44(23) (2014) 2577-2641. [29] I.H. Kim, N. Yamashita, Y. Kato, H. Tanaka, Discussion of the application of UV/ $\mathrm{H}_{2} \mathrm{O}_{2}$, $\mathrm{O}_{3}$ and $\mathrm{O}_{3} / \mathrm{UV}$ processes as technologies for sewage reuse considering the removal of pharmaceuticals and personal care products, Water Sci. Technol. 59(5) (2009) 945-955.

[30] A. Y. Hoekstra, Water scarcity challenges to business, Nat. Clim. Chang. 4 (2014) 318320.

[31] F. Yuan, C. Hu, X. Hu, D. Wei, Y. Chen, J. Qu, Photodegradation and toxicity changes of antibiotics in UV and UV/ $\mathrm{H}_{2} \mathrm{O}_{2}$ process, J. Haz. Mat. 185 (2011) 1256-1263. 
[32] O. Rozas, C. Vidal, C. Baeza, W.F. Jardim, A. Rossner, H.D. Mansilla, Organic micropolluttants (OMPs) in natural waters: oxidation by $\mathrm{UV} / \mathrm{H}_{2} \mathrm{O}_{2}$ treatment and toxicity assessment, Wat. Res. 98 (2016) 109-118.

[33] N.M. Reis, G. Li Puma, Novel microfluidics approach for extremely fast and efficient photochemical transformations in fluoropolymer microcapillary films, Chem. Commun. 51 (2015) 8414-8417.

[34] D. Russo, D. Spasiano, M. Vaccaro, R. Andreozzi, G. Li Puma, N.M. Reis, R. Marotta, Direct photolysis of benzoylecgonine under UV irradiation at $254 \mathrm{~nm}$ in a continuous flow microcapillary array photoreactor, Chem. Eng. J. 283 (2016a) 243-250.

[35] D. Russo, D. Spasiano, M. Vaccaro, K.H. Cochran, S.D. Richardson, R. Andreozzi, G. Li Puma, N.M. Reis, R. Marotta, Investigation on the removal of the major cocaine metabolite (benzoylecgonine) in water matrices by $\mathrm{UV} / \mathrm{H}_{2} \mathrm{O}_{2}$ process by using a flow microcapillary film array photoreactor as an efficient experimental tool, Wat. Res. 89 (2016b) $375-383$.

[36] D. Spasiano, D. Russo, M. Vaccaro, A. Siciliano, R. Marotta, M. Guida, N.M., Reis, G. Li Puma, R. Andreozzi, Removal of benzoylecgonine from water matrices through $\mathrm{UV}_{254} / \mathrm{H}_{2} \mathrm{O}_{2}$ process: reaction kinetic modelling, ecotoxicity and genotoxicity assessment, $\mathrm{J}$. Haz. Mat. 318 (2016) 515-525.

[37] I.C. Eom, C. Rast, A.M. Veber, P. Vasseur, Ecotoxicity of a polycyclic aromatic hydrocarbon (PAH)-contaminated soil, Ecotox. Environ. Safe. 67 (2007) 190-205.

[38] O.A. Olivero, G.M. Shearer, C.A. Chougnet, A.A. Kovacs, R. Baker, A.M. Stek, M.M. Khoury, M.C. Poirier, Incorporation of zidovudine into cord blood DNA of infants and peripheral blood DNA of their HIV-1-positive mothers, Ann. N. Y. Acad. Sci. 918 (2000) $262-268$. 
[39] O.A. Olivero, Mechanisms of genotoxicity of nucleoside reverse transcriptase inhibitors Environ. Mol. Mutagen. 48 (2007) 215-223.

[40] A. Dutra, E. Pak, S. Wincovitch, K. John, M.C. Poirier, O.A. Olivero, Nuclear bud formation: a novel manifestation of zidovudine genotoxicity, Cytogenet. Genome Res. 128 (2010) 105-110.

[41] I. Nicole, J. De Laat, M. Doré, J.P. Duguet, C. Bonnel, Use of UV radiation in water treatment: measurement of photonic flux by hydrogen peroxide actinometry, Wat. Res. 24 (1990) 157-168.

[42] S. Goldstein, D. Aschengrau, Y. Diamant, J. Rabani, Photolysis of aqueous $\mathrm{H}_{2} \mathrm{O}_{2}$ : quantum yield and applications for polychromatic UV actinometry in photoreactors, Env. Sci. Tech. 41 (2007) 7486-7490.

[43] ISO 6341:2012. Water quality: determination of the inhibition of the mobility of Daphnia magna Straus (Cladocera, Crustacea) — acute toxicity test.

[44] ISO 11348-3:2007. Water quality -- Determination of the inhibitory effect of water samples on the light emission of Aliivibrio fischeri (Luminescent bacteria test) -- Part 3: Method using freeze-dried bacteria.

[45] ISO 8692:2012. Water quality-Fresh water algal growth inhibition test with unicellular green algae.

[46] M. Guida, M. Inglese, S. Meric, A multi-battery toxicity investigation on fungicides, Desalination 226(1-3) (2008) 262-270.

[47] B.N. Ames, J. McCann, E. Yamasaki, Methods for detecting carcinogens and mutagens with the Salmonella/mammalian-microsome mutagenicity test, Mutat. Res. 31(6) (1975) 347364.

[48] EBPI, The Muta-chromoPlate Kit S-9 version 3.1. In E. B. P. Inc. (Ed.) 2005. 
[49] K. Piekarska, J. Karpinska-Smulikowska, Mutagenic activity of environmental air samples from the area of Wroclaw, Poland. Polish J. Environ. Stud. 16 (2007) 745-752.

[50] Y. Oda, S. Nakamura, I. Oki, T. Kato, H. Shinagawa, Evaluation of the new system (umu-test) for the detection of environmental mutagens and carcinogens, Mutat. Res. 147(5) (1985) 219-229.

[51] ISO 13829:2000. Water Quality- Determination of the genotoxicity of water and waste water using the umu-test.

[52] J.W. Tukey, Comparing individual means in the analysis of variance, Biometrics 5 (1949) 99-114.

[53] A. Dunge, A.K. Chakraborti, S. Singh, Mechanistic explanation to the variable degradation behaviour of stavudine and zidovudine under hydrolytic, oxidative and photolytic conditions, J. Pharm. Biomed. Anal. 35(4) (2004) 965-70.

[54] S. Goldstein, D. Aschengrau, Y. Diamant, J. Rabani, Photolysis of aqueous $\mathrm{H}_{2} \mathrm{O}_{2}$ : quantum yield and applications for polychromatic UV actinometry in photoreactors, Env. Sci. Tech. 41 (2007) 7486-7490.

[55] G.V. Buxton, C.L. Greenstock, W.P. Helman, A.B. Ross, Critical review of rate constants for reactions of hydrated electrons, hydrogen atoms and hydroxyl radicals $(\mathrm{OH} / \mathrm{O})$ in aqueous solution, J. Phys. Chem. Ref. Data 17 (1988) 513-886.

[56] B.H. Bielski, D.E. Cabelli, R.L. Aruda, A.B. Ross, Reactivity of $\mathrm{HO}_{2} / \mathrm{O}_{2}$ radicals in aqueous solution, J. Phys. Chem. Ref. Data 14 (1985) 1041-1077.

[57] C. Prasse, J.. Wenk, J.T. Jasper, T.A. Ternes, D.L. Sedlak, Co-occurrence of photochemical and microbiological transformation processes in open-water unit process wetlands, Environ. Sci. Technol. 49 (2015) 14136-14145.

[58] P. Onstein, M.I. Stefan, J.R. Bolton, Competition kinetics methos for the determination of rate constants for the reaction of hydroxyl radicals with organic pollutants using the 
$\mathrm{UV} / \mathrm{H}_{2} \mathrm{O}_{2}$ advanced oxidation technology: the rate constants for the tert-buthyl formate ester and 2,4-dinitrophenol, J. Adv. Oxid. Technol. 4(2) (1999) 231-236.

[59] J. K. Stanley, E.J. Perkins, T. Habib, J. G. Sims, P. Chappell, B. L. Escalon, M. Wilbanks, N. Garcia-Reyero, The good, the bad, and the toxic: approaching hormesis in Daphnia magna exposed to an energetic compound, Environ. Sci. Technol., 47 (16) (2013) 9424-9433.

[60] S. Li, Y. Tan, Hormetic response of cholinesterase from Daphnia magna in chronic exposure to triazophos and chlorpyrifos, J. Environ. Sci. (China) 23(5) (2011) 852-859.

[61] N. Cedergreen, J. C. Streibig, P. Kudsk, S. K. Mathiassen, S. O. Dukec, The Occurrence of hormesis in Plants and Algae, Dose Response 5(2) (2007) 150-162. 
Stavudine

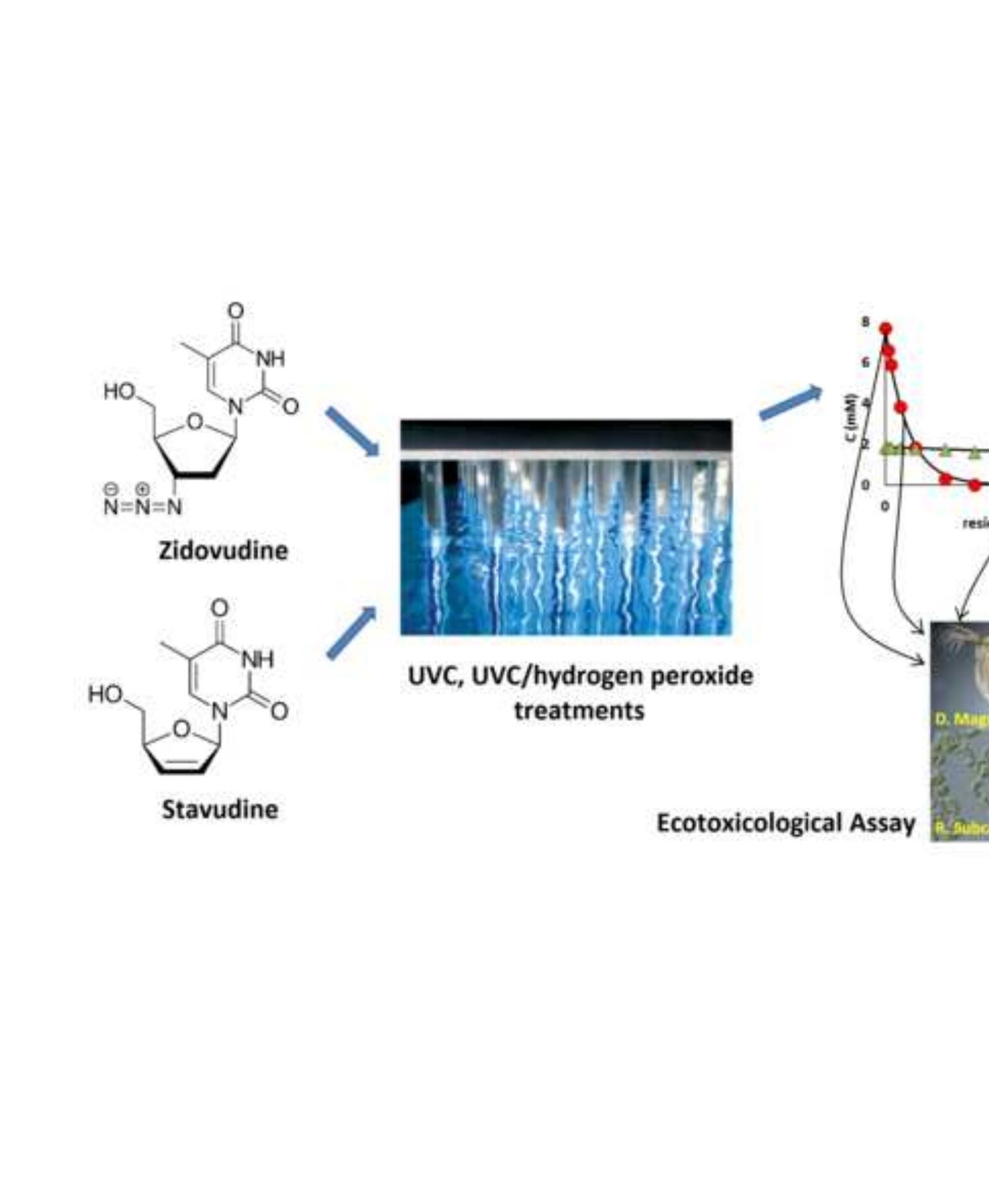

UVC, UVC/hydrogen peroxide treatments
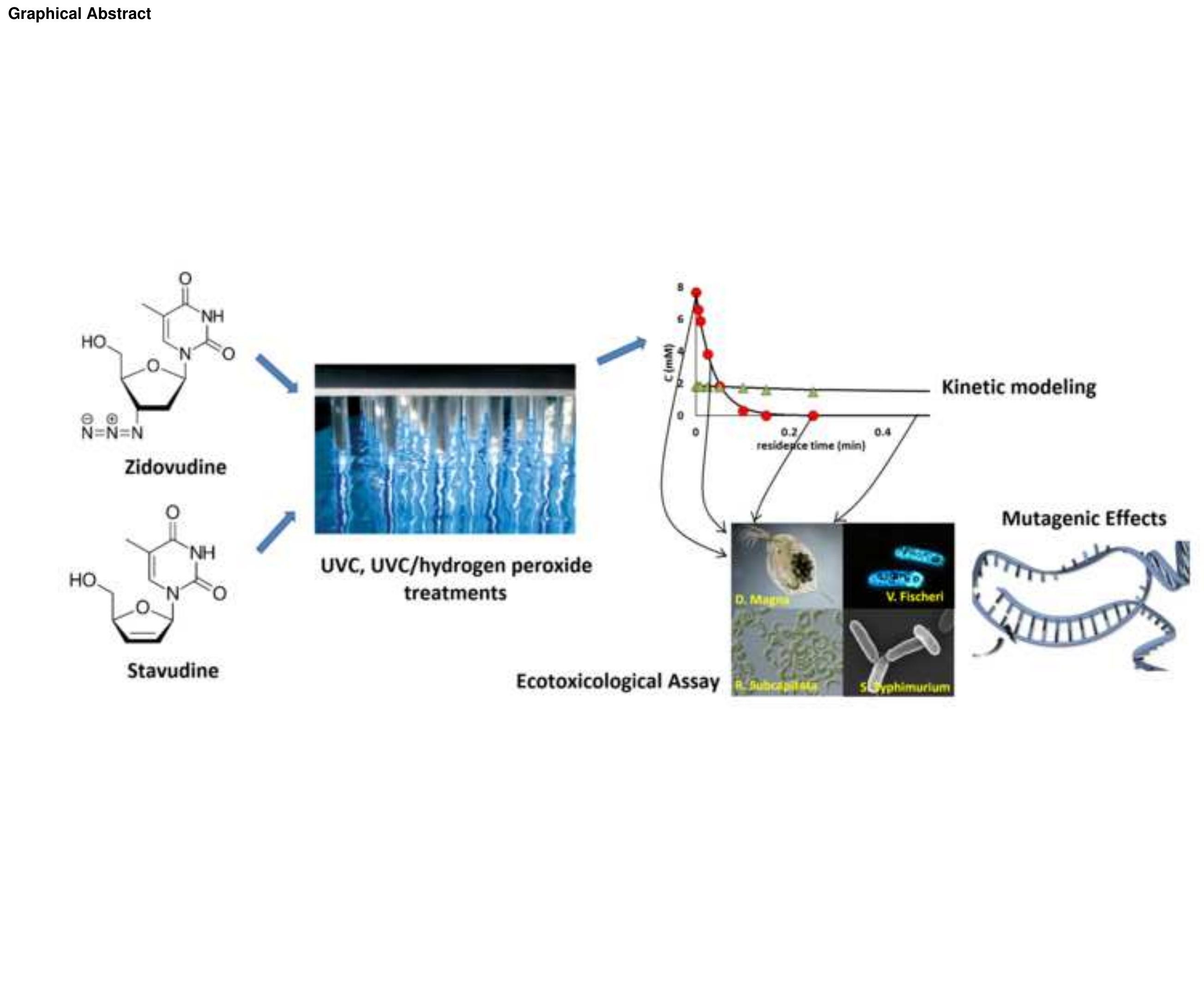

\section{Ecotoxicological Assay}

Mutagenic Effects

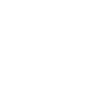


Removal kinetics of Zidovudine and Stavudine under $\mathrm{UV}_{254}$ and $\mathrm{UV}_{254} / \mathrm{H}_{2} \mathrm{O}_{2}$ were studied Zidovudine and Stavudine quantum yields at $254 \mathrm{~nm}$ were estimated

Kinetic constants of reaction between $\mathrm{OH}$ radicals and antiretrovirals were estimated No acute/chronic effects of treated and untreated samples on Vibrio $f$. and Daphnia m. Mutagenic/genotoxic activity of treated and untreated diluted samples on Salmonella t. 


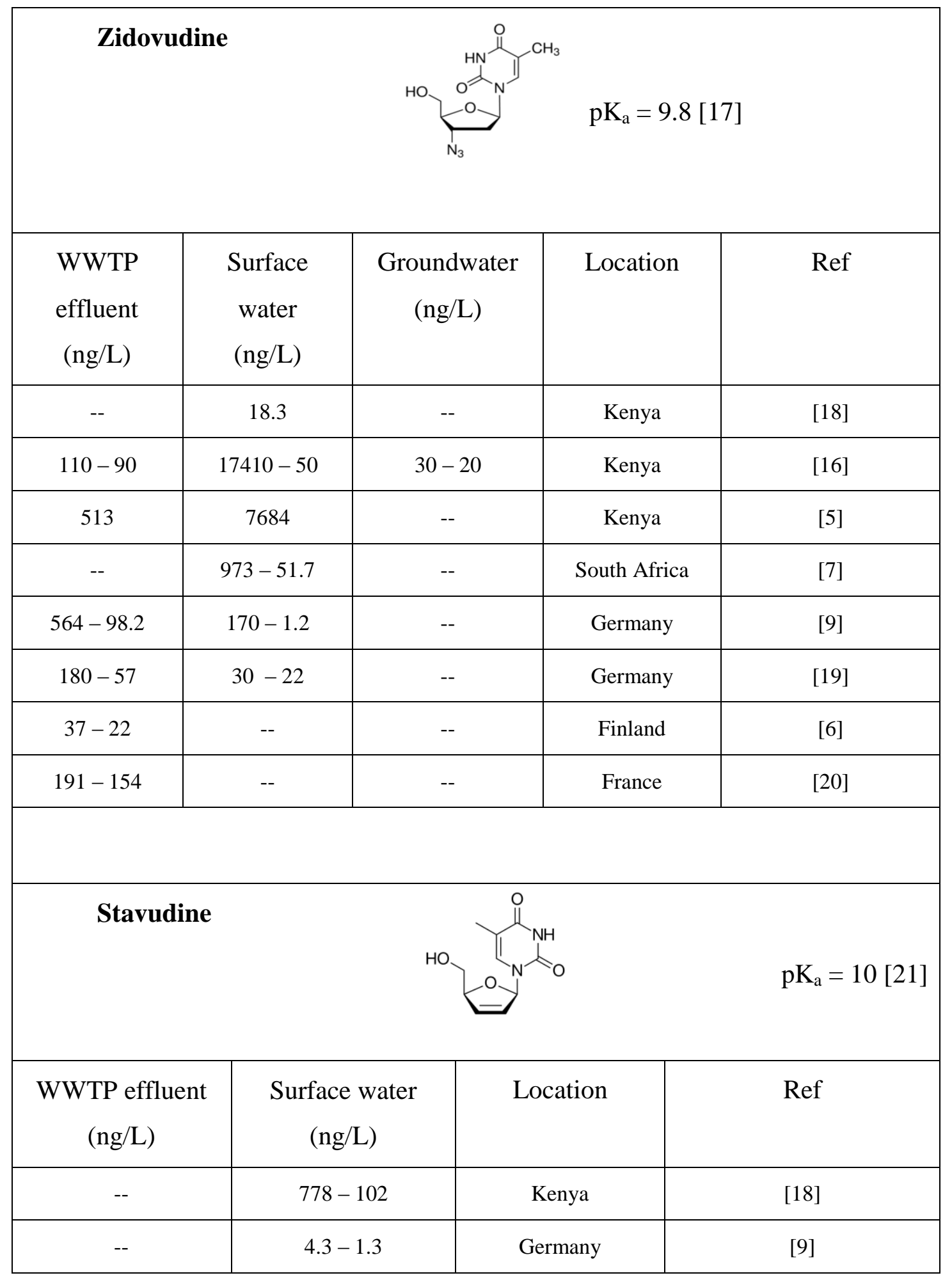

Table 1 


\begin{tabular}{|l|c|c|}
\hline & $\varepsilon_{i}^{254 n m}\left(M^{-1} \cdot \mathrm{cm}^{-1}\right)$ & $\mathrm{pH}$ range \\
\hline ZDV & $1.19 \cdot 10^{4}$ & $4-8$ \\
\hline STV & $7.81 \cdot 10^{3}$ & $6-8$ \\
\hline
\end{tabular}

Table 2 


\begin{tabular}{|l|c|c|}
\hline & $\phi_{i}^{254}\left(\mathrm{~mol} \cdot \mathrm{ein}^{-1}\right)$ & $\mathrm{pH}$ range \\
\hline ZDV & $(2.357 \pm 0.0589) \cdot 10^{-2}$ & $4-8$ \\
\hline STV & $(8.34 \pm 0.334) \cdot 10^{-4}$ & $6-8$ \\
\hline
\end{tabular}

Table 3 


\begin{tabular}{|c|c|c|c|c|}
\hline \multicolumn{5}{|c|}{ ZDV (optimization mode) } \\
\hline Run & $\mathrm{C}_{0} \cdot 10^{5}(\mathrm{M})$ & pH & $\begin{array}{c}\text { lamp nominal } \\
\text { power }(W)\end{array}$ & $\sigma(\%)$ \\
\hline 1 & 3.76 & 6 & 8 & 1.27 \\
\hline 2 & 3.67 & 4 & 8 & 0.55 \\
\hline 3 & 1.86 & 6 & 8 & 1.22 \\
\hline 4 & 1.83 & 4 & 8 & 1.57 \\
\hline 5 & 1.86 & 6 & 4.5 & 1.98 \\
\hline \multicolumn{5}{|c|}{ ZDV (simulation mode) } \\
\hline 6 & 3.65 & 8 & 8 & 0.48 \\
\hline 7 & 3.76 & 6 & 4.5 & 1.14 \\
\hline \multicolumn{5}{|c|}{ STV (optimization mode) } \\
\hline 8 & 4.49 & 6 & 8 & 1.65 \\
\hline 9 & 4.46 & 8 & 8 & 1.39 \\
\hline 10 & 2.27 & 6 & 8 & 3.87 \\
\hline \multicolumn{5}{|c|}{ STV (simulation mode) } \\
\hline 11 & 4.49 & 6 & 4.5 & 2.41 \\
\hline
\end{tabular}

Table 4 


\begin{tabular}{|c|c|c|c|c|c|}
\hline \multicolumn{6}{|c|}{ ZDV (optimization mode) } \\
\hline Run & $\mathrm{C}_{0} \cdot 10^{5}(\mathrm{M})$ & {$\left[\mathrm{H}_{2} \mathrm{O}_{2}\right]_{0} \cdot 10^{3}(\mathrm{M}$} & pH & $\begin{array}{c}\text { lamp } \\
\text { nominal } \\
\text { power }(W)\end{array}$ & $\sigma(\%)$ \\
\hline 1bis & 4.89 & 0.7 & 6 & 4.5 & 1.60 \\
\hline 2bis & 4.69 & 1.61 & 6 & 4.5 & 0.90 \\
\hline 3bis & 4.78 & 2.02 & 4 & 4.5 & 0.33 \\
\hline 4bis & 4.86 & 2.69 & 6 & 4.5 & 0.36 \\
\hline 5bis & 4.87 & 3.49 & 6 & 4.5 & 0.63 \\
\hline \multicolumn{6}{|c|}{ ZDV (simulation mode) } \\
\hline 6bis & 4.74 & 1.79 & 8 & 4.5 & 0.83 \\
\hline 7bis & 4.80 & 1.87 & 6 & 8 & 1.59 \\
\hline \multicolumn{6}{|c|}{ STV (optimization mode) } \\
\hline 8bis & 4.47 & 1.83 & 6 & 4.5 & 3.74 \\
\hline 9bis & 4.48 & 2.99 & 6 & 4.5 & 2.58 \\
\hline 10bis & 4.47 & 4.17 & 6 & 4.5 & 3.74 \\
\hline 11bis & 4.43 & 4.16 & 8 & 4.5 & 2.57 \\
\hline 12bis & 4.47 & 1.83 & 6 & 8 & 1.82 \\
\hline \multicolumn{6}{|c|}{ STV (simulation mode) } \\
\hline 13bis & 4.38 & 4.09 & 8 & 8 & 1.17 \\
\hline
\end{tabular}

Table 5 


\begin{tabular}{|l|c|c|}
\hline & $k_{O H, i}\left(M^{-1} \cdot s^{-1}\right)$ & $\mathrm{pH}$ range \\
\hline ZDV & $(9.98 \pm 0.68) \cdot 10^{8}$ & $4-8$ \\
\hline STV & $(2.03 \pm 0.18) \cdot 10^{9}$ & $6-8$ \\
\hline
\end{tabular}

Table 6 


\begin{tabular}{|c|c|c|c|c|c|c|c|c|c|}
\hline & \multirow{3}{*}{$\begin{array}{c}\text { Dilution } \\
\text { factor }\end{array}$} & \multicolumn{4}{|c|}{ Mutagenic ratio } & \multicolumn{4}{|c|}{ Induction ratio } \\
\hline & & \multicolumn{4}{|c|}{ Conversion degree (\%) } & \multicolumn{4}{|c|}{ Conversion degree $(\%)$} \\
\hline & & $\mathbf{0}$ & 45 & 90 & 100 & $\mathbf{0}$ & 45 & 90 & 100 \\
\hline & 1 & 8.1 & 2.4 & 9.1 & 9.3 & 1.2 & 2.1 & 2.9 & 1.0 \\
\hline \multirow{2}{*}{$\mathbf{U V} \mathbf{V}_{254}$} & $10^{-1}$ & 4.3 & 1.5 & 5.5 & 5.9 & 0.2 & 1.5 & 1.7 & 0.8 \\
\hline & $10^{-2}$ & 2.7 & 1 & 3.3 & 3.7 & ND & 1.9 & 1.5 & 0.2 \\
\hline \multirow{5}{*}{$\mathrm{UV}_{254} / \mathrm{H}_{2} \mathrm{O}_{2}$} & $10^{-3}$ & 2 & ND & 2.6 & 2.8 & ND & ND & ND & ND \\
\hline & 1 & 7.9 & 6.5 & 2.9 & 0.8 & 1.5 & 0.5 & 3.1 & 0.9 \\
\hline & $10^{-1}$ & 6 & 4.9 & 0.5 & 0.3 & 0.7 & ND & 1.6 & 0.6 \\
\hline & $10^{-2}$ & 2.1 & 0.7 & ND & ND & ND & ND & 1.6 & ND \\
\hline & $10^{-3}$ & ND & ND & ND & ND & ND & ND & ND & ND \\
\hline
\end{tabular}

Table 7 


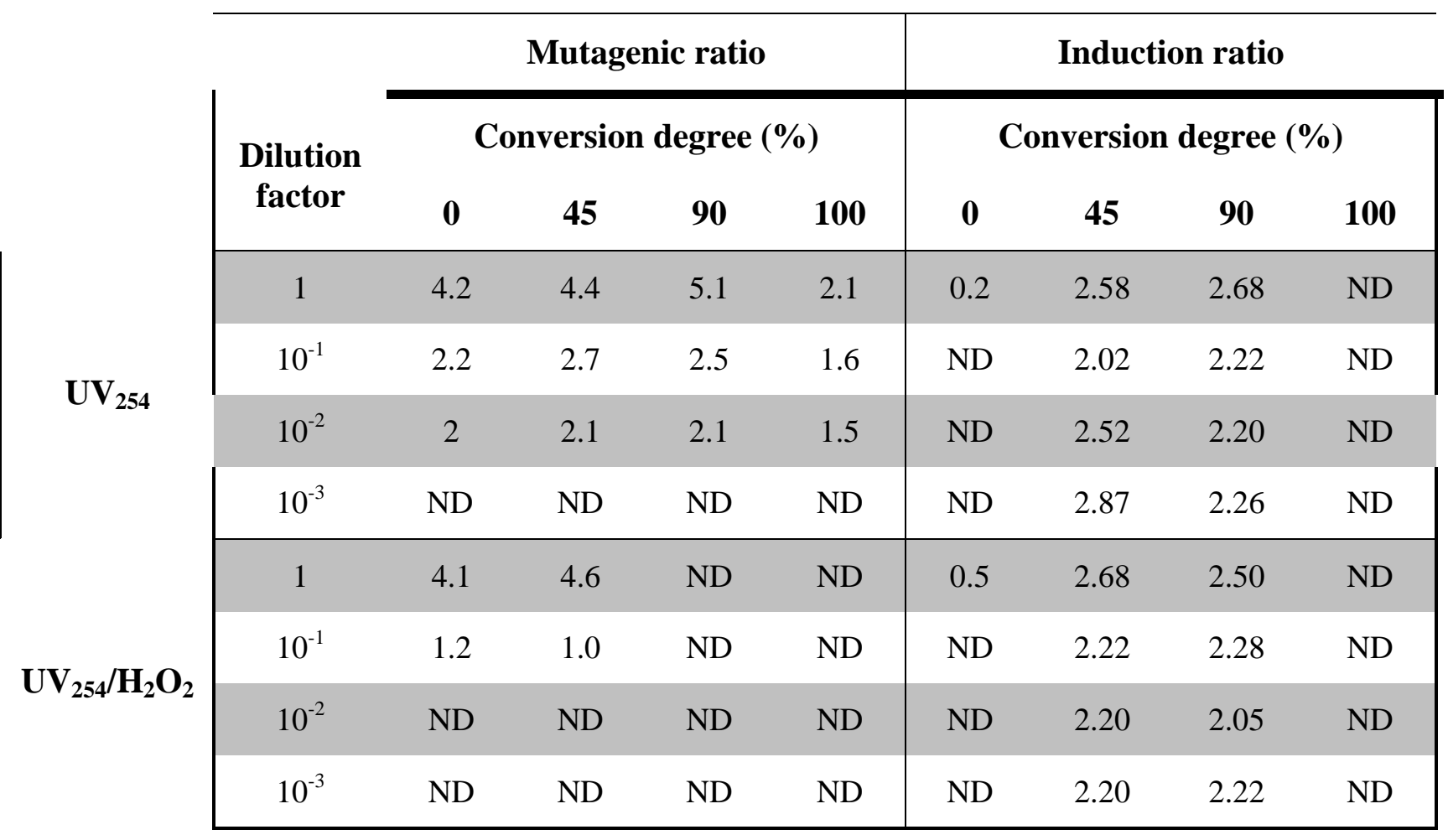

Table 8 

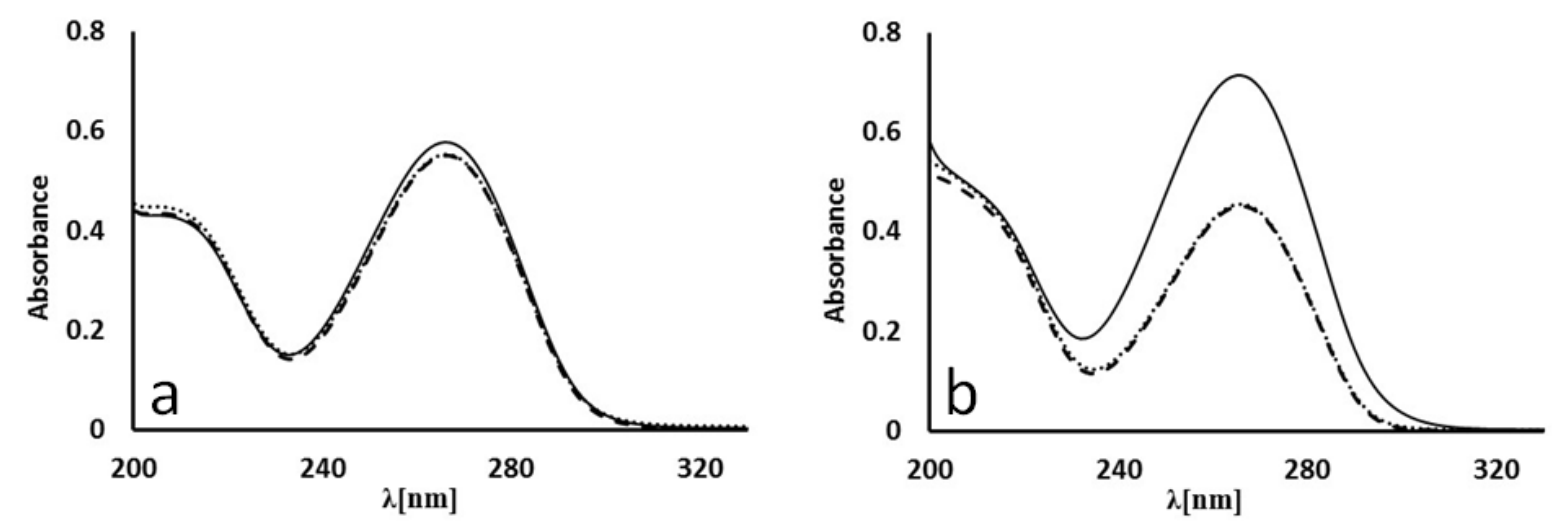

Figure 1 


\section{OPTIMIZATION MODE}
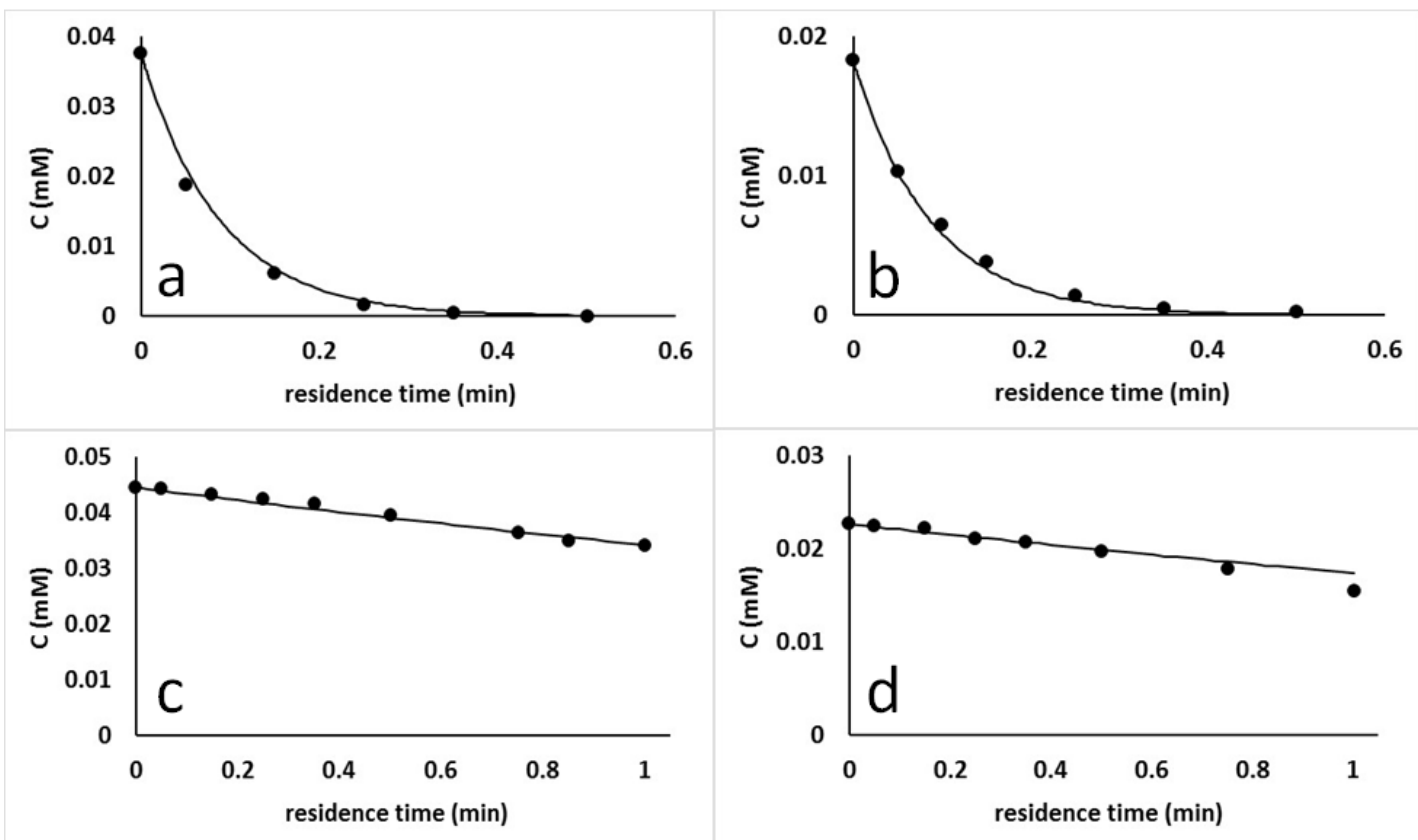

SIMULATION MODE
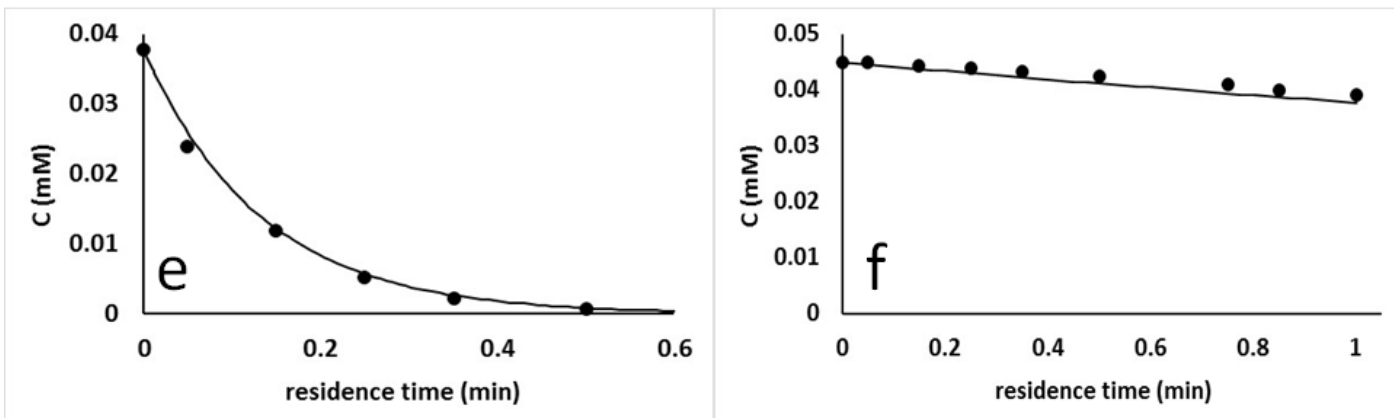

Figure 2 

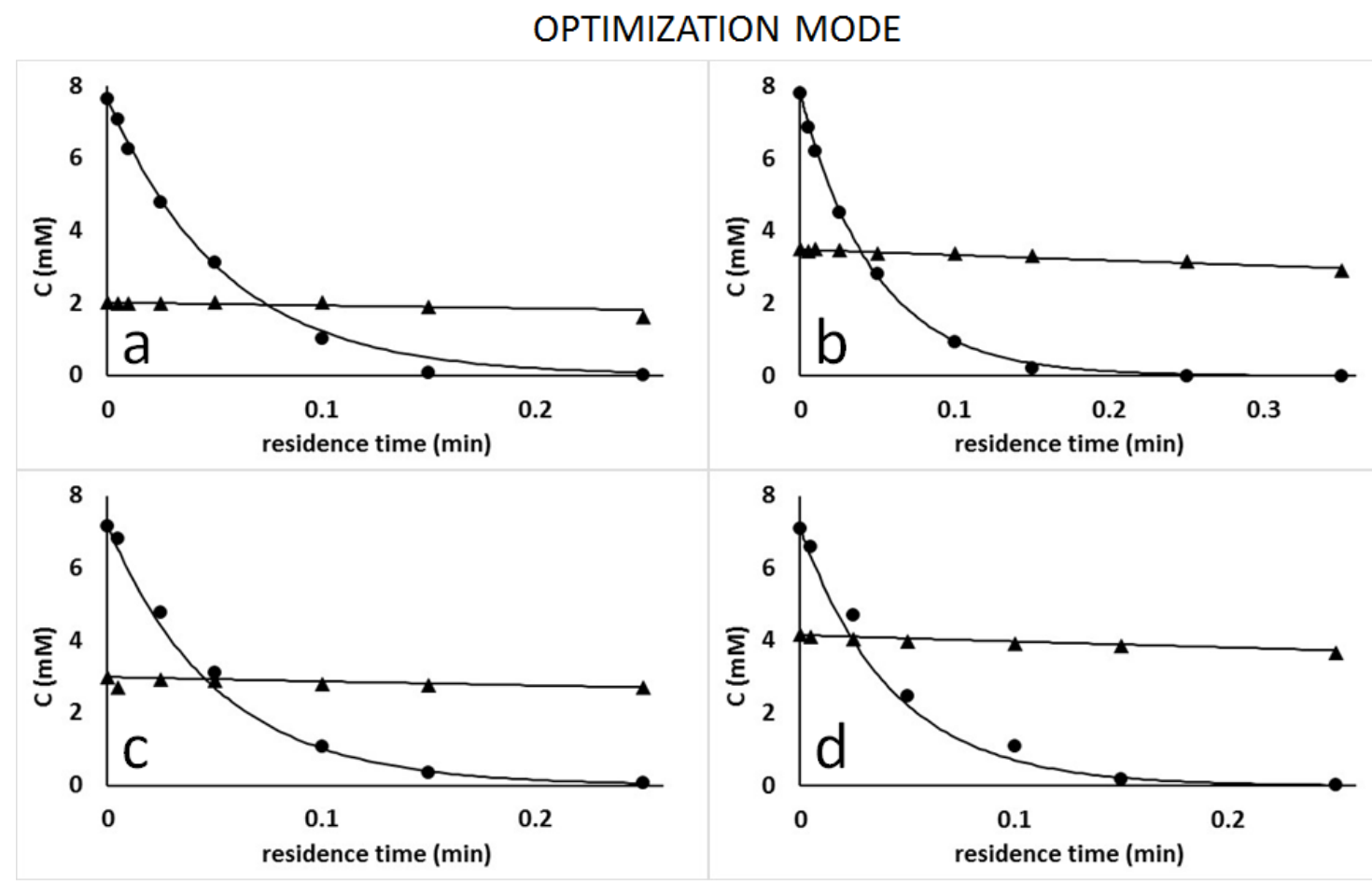

SIMULATION MODE
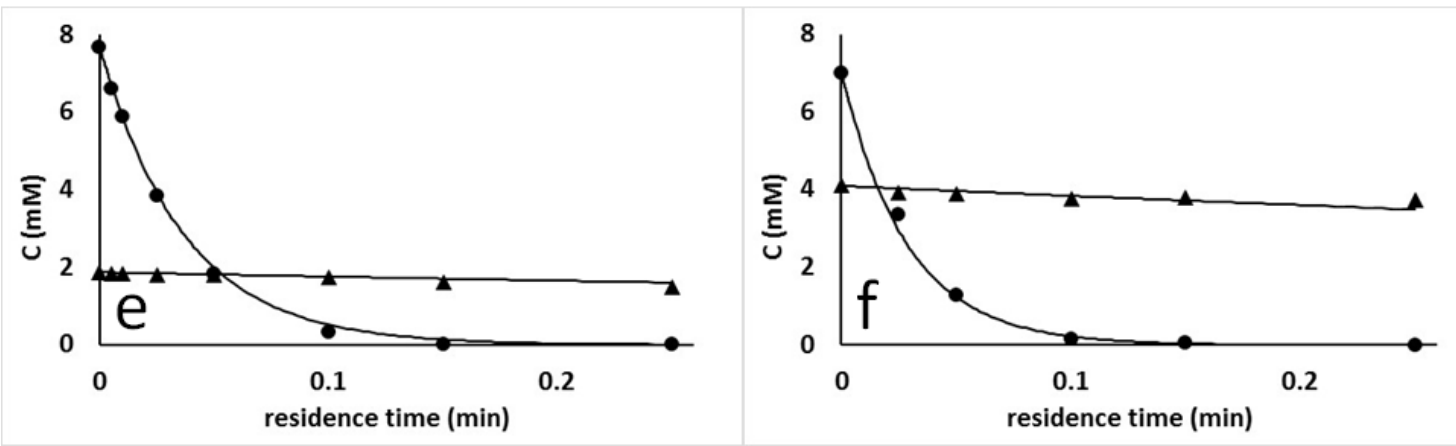

Figure 3 

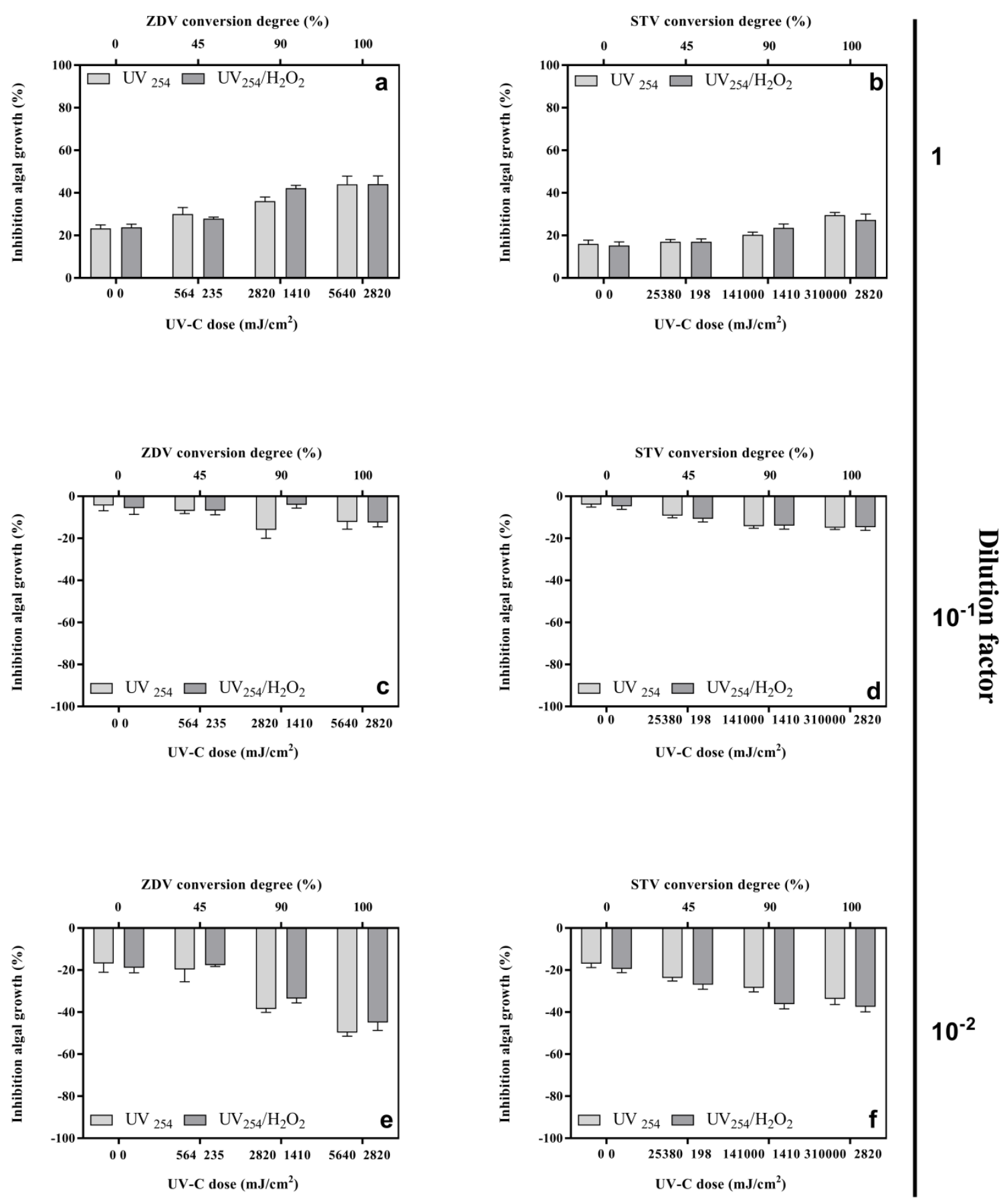

Figure 4 

Table 1 - Levels of zidovudine and stavudine in WWTPs effluents, surface water, and ground water. Table 2 - Estimated molar absorption coefficient of ZDV and STV.

Table 3 - Estimated direct photolysis quantum yields of ZDV and STV at $254 \mathrm{~nm}$.

Table 4 - Experimental runs and experimental conditions used for the estimation of quantum yields photolysis at $254 \mathrm{~nm}$ of ZDV and STV along with percentage standard deviation $(\% \sigma)$.

Table 5 - Experimental runs and experimental conditions for $k_{O H, i}$ estimation of ZDV and STV along with percentage standard deviation $(\% \sigma)$.

Table 6 - Estimated kinetic constant of hydroxyl radical attack to ZDV and STV with 97\% confidence interval.

Table 7 - Mutagenic results from Ames and Umu tests for ZDV treated solutions. Starting concentration: $4.5 \mathrm{mg} \cdot \mathrm{L}^{-1}$.

Table 8 - Mutagenic results from Ames and Umu tests for STV treated solutions. Starting concentration: $4.35 \mathrm{mg} \cdot \mathrm{L}^{-1}$.

Fig. 1 - Absorbance spectra of ZDV (a) and STV (b). $\mathrm{C}_{\text {init }}=5 \cdot 10^{-5} \mathrm{M} .(-) \mathrm{pH}=4.0$; (- - -) $\mathrm{pH}=$ $6.5 ;(\cdots) \mathrm{pH}=8.0$.

Fig. 2 - Comparison between experimental (symbols) and calculated (continuous lines) data for the direct photolysis of $\operatorname{ZDV}(a, b, e)$ and $\operatorname{STV}(c, d, f)$ under $\mathrm{UV}_{254}$ irradiation. Experimental conditions are summarized in Table $4(a-1 ; b-4 ; c-9 ; d-10 ; e-6 ; f-11)$.

Fig. 3 - Comparison between experimental (symbols) and calculated (continuous lines) data for the $\mathrm{UV}_{254} / \mathrm{H}_{2} \mathrm{O}_{2}$ degradation of $\mathrm{ZDV}(a, b, e)$ and $\operatorname{STV}(c, d, f)$. Experimental conditions are summarized in Table 5 (a-3bis; b-5bis; c-9bis; d-11bis; e-7bis; f-13bis). ZDV and STV concentrations are multiplied by 160 for visual convenience.

Fig. 4: Inhibition algal growth (R. subcapitata) for solutions containing the selected antiretrovirals by $\mathrm{UV}_{254}$ and $\mathrm{UV}_{254} / \mathrm{H}_{2} \mathrm{O}_{2}$. Starting concentration: $4.5 \mathrm{mg} \cdot \mathrm{L}^{-1}$ for $\mathrm{ZDV}, 4.35 \mathrm{mg} \cdot \mathrm{L}^{-1}$ for $\mathrm{STV}$. Data with different letters $(\mathrm{a}-\mathrm{d})$ are significantly different $(\mathrm{p}<0.05)$. 